\title{
Just doing gender? Transvestism and the power of underdoing gender in everyday life and work
}

Torkild Thanem \& Louise Wallenberg, Stockholm University, Sweden

The final version of this paper is published in Organization (2014), Online First: dx.doi.org/10.1177/1350508414547559

\begin{abstract}
While previous research in organization studies has utilized transgender to show how gender is done, overdone and undone, this literature lacks empirical grounding, and the theoretical arguments dominating it tend to idealize the transgressive power of transgender whilst reducing transgender to hyperbolic drag and stereotypical passing. To further advance the understanding of transgender within and around organizations, this paper presents a qualitative study from a Northern European country to investigate how male-to-female transvestites do and undo gender in everyday life and work. In contrast to extant research, we found that participants did transgender and undid gender by underdoing gender, that is, by combining feminine, masculine and un-gendered practices and attributes in ways that made passing and drag insignificant. As transvestites simultaneously expressed masculine and feminine forms of embodiment, we argue that they may more obviously challenge, though not dismantle, dominant forms of gender and identity than suggested by previous accounts. We conclude by discussing broader implications for the understanding of gender, identity, power and resistance in organizations.
\end{abstract}

Keywords: Undoing gender; passing; transgender; stigmatized identities at work; power; resistance. 


\section{Introduction}

In recent years the doing and undoing of gender has attracted increasing attention in organization studies. Some of this literature has drawn on West and Zimmerman's (1987) notion of doing gender, which assumes that people manage social situations in ways that make their behaviour and display gender "appropriate" or "inappropriate". Thus, it has highlighted how women and men in organizations do gender appropriately by constructing, expressing and maintaining binary gender roles and identities through everyday social practices (e.g. Tyler and Abbott 1998; Bruni et al. 2004; Czarniawska 2006). In contrast, and following Butler $(1990,1993,2004)$, research on undoing gender has emphasized how gender roles and identities are undone negatively and positively. Negative undoing concerns practices that restrict the range of liveable gender roles and identities, making gender expressions that do not conform to dominant gender norms unliveable or less liveable, and it may be produced through social and discursive practices that devalue and disqualify women in male-dominated work environments (e.g. Pullen and Knights 2007; Powell et al. 2009; Kelan 2010) or stigmatize and stereotype women and men engaged in dirty work (Tyler 2012). Positive undoing involves practices that challenge, though not necessarily dismantle, such boundaries by making a wider range of gender roles and identities liveable, and it may emerge through discursive, social and bodily practices that blur and transgress the gender binary as women and men overdo gender stereotypes or adopt gender practices and attributes primarily associated with the opposite sex (e.g. Brewis et al. 1997; Linstead and Pullen 2006; Tyler 2012). In the 
latter literature, transgender is sometimes utilized as an ideal case of undoing gender (Brewis et al. 1997; Linstead and Pullen 2006; see also Thanem 2004, 2010), thereby contradicting previous arguments in second-wave feminism, which argue that male-to-female transgender people exaggerate and reinforce gender stereotypes, ridicule women and stabilize the gender binary (e.g. Raymond 1979; Greer 1999).

Notwithstanding these contributions, there is limited empirical research on how transgender people do and undo gender, and there are hitherto no empirical studies of transvestites in settings of work and organization. Moreover, the theoretical arguments above are problematic for a number of reasons: as they tend to treat transgender as a disembodied metaphor of un-gendering and gender transgression, they risk exaggerating the transgressive power of transgender; and as they tend to associate gender transgression with hyperbolic drag and stereotypical practices of passing, they ignore how gender transgression may be expressed in more nuanced and subtle ways. Conversely, the extremely small number of empirical studies that have investigated transgender in settings of work and organization have emphasized the difficulty of doing gender differently: even when trying to make gender trouble, that is, even when intentionally seeking to challenge stereotypical and binary gender roles and identities, transgender employees have been folded into these same roles and identities by colleagues (Schilt and Connell 2007). No doubt, transgender is a contested issue, and this is aggravated as key terms are confused in parts of the literature (e.g. in West and Zimmerman 1987 and in Ward and Winstanley 2003). ${ }^{1}$

Before moving on, let us therefore define the terms transgender, 
transvestism and transsexuality as well as the more recent term gender queer. As stated in one specialist dictionary, a transgender person is someone 'who lives as a member of a gender other than that expected based on anatomical sex' (Green and Peterson 2006: 9). This suggests that transgender people live full-time as members of a gender category different from that assigned at birth but without undergoing sex reassignment surgery. However, this refers to a somewhat limited group, ignoring that transgender is widely used as an umbrella term that includes transsexuals, transvestites, gender queers and others who do not conform to the male/female binary (see e.g. Ekins and King 2006). We will therefore use the latter definition in this paper.

Meanwhile, a transsexual is someone who identifies as a member of a gender other than that assigned at birth, and transsexuals typically seek to undergo hormone replacement therapy and sex reassignment surgery to align their anatomy and physical appearance with their gender identity. In contrast, a transvestite is someone who dresses in clothing usually associated with the opposite sex. Unlike transsexuals, many transvestites identify both with the gender they were assigned at birth and with the opposite gender, and generally do not wish to undergo sex reassignment surgery. In North America, the term crossdresser is often preferred because the term transvestite is seen as a pejorative medical label. However, this is rarely the case in Europe, where many transvestites embrace the term. Other people who identify both with the gender they were assigned at birth and with the opposite gender sometimes use the term gender queer. But unlike most transvestites, gender queers tend to mix striking forms of feminine and masculine display full-time as part of an activist agenda of gender 
transgression. Moreover, many gender queers undergo hormone replacement therapy and mastectomy but not genital reassignment surgery.

We should point out that transgender, transsexuality, transvestism and gender queering are matters of gender identity unrelated to sexual orientation (e.g. ibid). We also acknowledge that these categories have some fluidity: some transvestites and gender queers may later identify as transsexual; some transsexuals have regretted post-surgery that they transitioned; and some transvestites prefer the more open-ended terms transgender, trans person or trans people. Finally, we should stress that there is a term for "everybody else" who are not transgender: "cisgender", from the Latin, where cis is the antonym of trans.

Given the limited empirical research on transgender in work and organizational settings and the somewhat one-sided arguments of the theoretical transgender literature in organization studies, we seek to contribute to the understanding of doing and undoing gender within and around organizations by further exploring how transgender people do and undo gender in everyday life and work, and what implications this may have for gender relations in organizations. More precisely, we are interested in how, and how far, transgender people make gender trouble, that is, how the gender practices of transgender people may challenge, or maintain, the power of dominant gender norms. Do transgender people make as much gender trouble as previous accounts have suggested? Who may be troubled by transgender colleagues at work? How troubled would they be? And who may benefit from the gender trouble created by transgender people?

Since we suspect that transgender people express and experience 
transgender in more ambiguous ways than suggested in the extant literature, we focus on male-to-female transvestites, a group which rarely figures in organization studies and in the transgender literature, and is less visible than other transgender groups within popular culture and within the LGBT community. Utilizing a variety of qualitative methods, we investigate how self-identified and primarily part-time male-to-female transvestites express and experience transgender in everyday life and work - their dress practices, the pains and pleasures related to their transvestism, how they manage their careers and relate to colleagues, and how this may challenge or maintain the power of dominant and binary gender norms. Indeed, how might transvestites enact dominant gender norms, and how may they experience such norms as constraining or enabling their transvestism? Further, to what extent might they experience their gender transgressions as acts of resistance?

Since transvestites often draw a sharp line between work and private life, we cannot limit this to settings of work and organization. We also need to consider how transgender is expressed and experienced in everyday life more broadly. Since few transvestites are out at work, we are not merely concerned with the social and bodily practices that transvestites mobilize in expressing transgender, but also with the practices they might mobilize to repress and conceal transgender. Indeed, this may say something significant about the power of binary gender norms, gender stigma and workplace subjectification, and how transvestites experience this.

This focus on transvestism is no attempt to essentialize and separate different transgender experiences, but important in order to bring out experiences 
and practices hitherto neglected in the literature. Our main argument is that maleto-female transvestites do not primarily do transgender by copying or overdoing stereotypically feminine gender attributes and practices. Transvestites do also not redo gender by redefining the qualities associated with female and male gender roles (see West and Zimmerman 2009; Connell 2010). Rather, transvestites do transgender by underdoing gender, that is, by adding, removing and combining feminine, masculine and un-gendered practices and attributes. Transgender, then, is not necessarily about passing as a member of the opposite sex by expressing a common or idealized feminine stereotype, or about exaggerating such a stereotype through drag. Transgender, we argue, may involve adopting a heterogeneous mixture of gendered and un-gendered practices and attributes in subtle and transitory ways, thus embodying a gender terrain between and beyond male and female gender roles and identities. By speaking of underdoing and overdoing gender, we do not intend to invoke essentialist notions of femininity and masculinity. Gender is necessarily done, overdone or underdone in relation to socially dominant gender norms.

While transgender in general and transvestism in particular has received little attention in organization studies, the sense that transvestites underdo gender may have significant implications for the broader understanding of identity practices and identity politics in organizations. Despite increasing pressure on employees to "just be themselves" at work (e.g. Fleming and Sturdy 2009), the limited visibility of transvestism in work organizations suggests that transvestites continue to struggle with this, fearing the consequences should they dress up, come out or be found out at work. Indeed, organizations constantly require 
employees with invisible stigma to make decisions about concealing or revealing their stigma (e.g. Ragins 2008). Whereas concealing and repressing stigmatized identities may have costs and consequences for individuals and organizations (e.g. Creed and Scully 2000), revealing and expressing such identities may challenge prevailing and idealized notions of employee identity. Consequently, transvestism - regardless of how strongly or how frequently it is concealed or revealed - is bound up with the expression of power, resistance and identity in organizations. As such, it may provide an extreme case of how identity practices more broadly are embedded in organizational processes of power and resistance.

The remainder of the paper is structured as follows. We first review the literature on the doing and undoing of gender and transgender as well as the literature on stigmatized identities in organizations. Secondly, we present our empirical setting and discuss the methods utilized to study male-to-female transvestites. Thirdly, we analyse our empirical findings in relation to the literatures above. Finally, we discuss what implications underdoing gender has for the expression of gender, identity, power and resistance in organizations.

\section{Understanding the doing and undoing of trans/gender in everyday life and work}

\section{Doing gender}

Assuming that gender is a fundamental part of social interaction and organization, West and Zimmerman (1987: 127) emphasize that people interact and organize their activities so as 'to reflect or express gender' and that people assume that other people also behave in this way. In turn, these activities are subject to 
commentary and characterization, and since we know that they are, we design and adapt our activities accordingly.

West and Zimmerman are heavily indebted to Garfinkel (1967): they argue that gender is structured by and structures social interaction; they invoke his case study of the transsexual woman Agnes to differentiate between biological sex and social gender; and they argue that social gender tends to correlate with biological sex - that most people express gender in ways that are deemed 'appropriate for one's sex category' (West and Zimmerman 1987: 127), thus proclaiming membership of that sex category. Doing gender, then, involves managing social situations in such a way that one's behaviour and display is regarded gender appropriate or inappropriate. In Garfinkel's terms, this involves sexual passing, that is, the deployment of bodily, linguistic and social practices (such as make-up, "lady-like" manners and rehearsed carelessness) to be successfully categorized as a member of the chosen sex. Or it involves the failure to pass.

While we do not always pass and live up to socially dominant norms of femininity or masculinity, West and Zimmerman insist that we always do gender, and that we do so regardless of the social situation or organizational context. Garfinkel's influence is persistent throughout, as they acknowledge that people might express gender in ways that do not correspond to their biological sex, but show more concern with how routine gendered practices produce and maintain the gender binary as a fundamental element of sexual-social order than with gender expressions that blur and disrupt it. ${ }^{2}$ Even their notion of redoing gender assumes that the gender binary as such remains intact, although the qualities of male and female gender may be redefined (see West and Zimmerman 2009). 
Finally, they are more concerned with how gender is constructed in general than with the real problems and opportunities people experience whilst doing gender.

Ekins' (1997) ethnographic research on how male-to-female transvestites do gender goes some way in resolving these shortcomings. Acknowledging the ambiguities and non-linearity of the social process of doing transgender, Ekins argues that this involves bodily and social practices of dressing up and managing identity, impressions and information, display and disclosure. Although passing was significant for some of his respondents, Ekins shows how transvestites seek to prevent disclosure by developing dual identities, for instance by crafting a private female self who enjoys housework and is stereotypically opposite to a public male self who enjoys sports.

Further, Ekins complicates the doing of transgender by showing how other transvestites sought to integrate their female and male identities into one transgender identity. This gives rise to a continuum of transgendering - from transvestites who embrace a female gender identity full-time, via transvestites who occasionally engage in stereotypically feminine roleplaying, to transvestites who wear female clothes in private but without seeking to express any female or transgender identity. Moreover, Ekins addresses the emotional aspects of transgendering. Many transvestites experience shame or guilt as well as erotic and psychological pleasure in relation to transgendering, and worry about reactions from family, friends and strangers - about being found out rather than coming out, about being stigmatized, excluded and harassed. Notwithstanding his rich material and significant findings, Ekins does not examine transvestism in relation to work and organization and he does little to problematize transvestism in relation to the 
gender binary and the un/doing of gender.

Meanwhile, organizational scholars have investigated how women and men construct, express and maintain binary gender roles by doing gender. This is well illustrated through Tyler and Abbott's (1998: 433) study of women flight attendants, who 'were required to "manage themselves as ornamental objects"' (West and Zimmerman 1987: 141 in ibid) to do gender appropriately at work. In order to accomplish a stereotypically feminine and sexually differentiated look, they were trained to deploy stipulated practices of body-work on a routine basis, including make-up, hairstyling and weight-watching. Male employees were not subjected to similar regulation. In a different vein, other studies have found that women entrepreneurs play the part of secretaries whilst interacting with customers in order to conform to dominant norms of entrepreneurship as a male domain (Bruni et al. 2004). As Czarniawska (2006: 236) has pointed out, such examples suggest that doing gender involves coercive and discriminatory practices where women and men 'treat women worse than they treat men.' While this literature emphasizes how doing gender maintains the gender binary, there is also a considerable literature on undoing gender, some of which highlights gender practices that might blur or transgress the gender binary.

\section{Undoing gender}

Several organizational scholars have drawn on Butler's work to investigate how gender is positively or negatively undone in settings of work and organization. Striking a chord with Czarniawska's (2006) argument about the discriminatory aspects of doing gender and drawing on Butler's (2004) notion of undoing, some of 
these studies have emphasized how female gender identities are negatively undone and made unliveable as a consequence of organizational pressures to do gender in stereotypically feminine ways or in ways that restrain their female identities. For instance, young women engineers have been found to mobilize gendered coping strategies such as "acting like a man" and "accepting gender discrimination" in order to gain male acceptance in a male-dominated environment, but ending up devaluing their own femaleness by doing so (Powell et al. 2009).

In a more positive vein, it has been argued that women Information Technology workers, who were frequently cast in a secretarial role by clients, were able to resist such negative undoing and positively undo gender simply by being a woman Information Technology worker in a male-dominated industry (Kelan 2010). Positive undoing of gender is more clearly brought out in Tyler's (2012) study of the dirty work performed by female and male sex shop workers. Despite being cast in stigmatized, devalued and to some extent stereotypical identities by virtue of working in a morally tainted industry, they were able to contribute to the positive undoing of gender by feeling proud and excited about working in a sexually diverse environment and by doing work which helped others express gender in a multiplicity of transgressive ways - as "glamour girls" who exaggerate feminine stereotypes through parody, as "macho men" who exaggerate masculine stereotypes through parody, and as "everything in between", such as "inbetweeners" who mix various elements of feminine and masculine stereotypes.

Issues of undoing gender are equally prevalent, albeit less explicit, in the organizational literature which has utilized transgender as an ideal case to 
illustrate gender multiplicity and the transgression of binary gender stereotypes. Assuming that the gender binary is a product of socially dominant norms, Brewis et al. (1997) argue that male-to-female transvestism highlights the constructed and contestable nature of gender and that it constitutes a dress practice, which, despite being deemed gender inappropriate by socially dominant norms, makes it possible to resist such norms. According to Brewis et al., transvestites contest the gender binary and the gender hierarchy which it implies by - occasionally or frequently but never permanently - adopting a completely different gender identity, by seeking to pass as a member of the opposite sex, and by moving between genders. Similarly, Linstead and Pullen (2006) have argued that gender cannot be reduced to a question of being female or male, and that transgender constitutes a middle position, which makes it possible to understand people as "multiplicitly" genderful or ungendered.

These arguments draw heavily on Butler's $(1990,1993)$ notion of gender performativity, and invoke transvestism and transsexuality as ideal cases to illustrate the performativity and positive undoing of gender. In contrast, Butler originally brought out the constructed and contestable nature of gender and the sex-gender relationship by highlighting how drag performers exaggerate and overdo gender practices and attributes. Although Butler concluded that all gender is drag, this suggests that the positive undoing of gender is primarily achieved by attracting rather than avoiding attention. Meanwhile, it is problematic that Butler's use of drag as a disembodied metaphor for understanding gender performativity in general leads her to ignore the real-life experiences, sufferings and joys of people who transgress dominant gender norms as well as the nuanced ways in which they 
perform gender (e.g. Namaste 1996; Thanem 2011).

As acknowledged by Brewis et al. (1997), this positive valuation of transgender has been highly contested by essentialist feminists (esp. Raymond 1979; Greer 1999), who assume that only women who are born women are real women. On this view, male-to-female transgendering is just another attempt by men to marginalize and dominate women. Advocating a positive appraisal of "true womanhood" based on a binary notion of sexual difference and a causal sex-gender relationship, they argue that transvestites and transsexuals create woman in a male image which reinforces sexist stereotypes of womanhood, picking and choosing superficial and sexualized aspects of femininity when convenient and abandoning them when risking sexual harassment, discrimination and stigmatization.

Empirical research sometimes works to moderate such theoretical extremes. Combining Butler's $(1990,1993,2004)$ notion of gender performativity with West and Zimmerman's (1987) notion of doing gender, Schilt and Connell (2007) problematize the ability of transsexuals to undo gender, move voluntarily between genders, and make gender trouble at work. Before transition, transwomen were expected to engage themselves in conversations about cars and sports with their male colleagues while transmen were expected to participate in "girl-talk" about appearance, dress and menstruation. After transition, transmen were excluded from girl-talk and transwomen found their professional capacities questioned by male co-workers. But even though same-gender interactions after transition were quite inclusive (e.g., as transwomen were included in women-only activities), those who deliberately tried to make gender trouble by expressing alternative 
femininities and masculinities found this very difficult. Rather, they were enlisted in rituals that reinforced stereotypical gender roles and the binary gender divide, and they went along with this to keep social relationships smooth during transition' and 'retain steady and comfortable employment' (ibid: 605).

Connell (2010) suggests that full-time female-to-male gender queers, who come out and are transparent as trans, may go somewhat further in challenging the gender binary by expressing hybrid gender identities that 'meld together masculine and feminine gender performances' (ibid: 39). Connell argues that this involves 'moments of undoing gender' insofar as gender queers are 'drawing attention to their disruption of the relationships between sex, gender, and sex category', but that it more strongly involves redoing gender because it does not 'eliminate gender as a sorting device' (ibid: 46-47).

We acknowledge this contribution, but would argue that Connell (2010) as well as West and Zimmerman (2009) conflate undoing gender with a dismantling of the gender binary, thus ignoring how undoing gender may challenge the gender binary by making a wider range of gender identities liveable. Moreover, the fulltime nature of gender queering and the repetitive connotations of redoing gender imply a limited dynamism, as emphasis is on individuals maintaining a certain form of gender expression rather than moving between different gender expressions.

In summary, these literatures help us investigate how transvestites do, undo, express and conceal transgender through various social and bodily practices. Whereas the literature on doing gender and passing is concerned with practices that typically maintain the gender binary and the causal sex-gender relationship, 
the literature on undoing gender draws attention to practices that challenge these. The small empirical literature on transvestites (Ekins 1997), transsexuals (Schilt and Connell 2007) and gender queers (Connell 2010) yields particular insights into how transgender people experience and express gender in everyday life and work. This helps us evaluate how, and how much, transvestites do and undo gender. We are unaware of any previous studies of transvestites in settings of work and organization, and we suspect that transvestites do gender differently from transsexuals and gender queers. Indeed, we will argue that the notion of underdoing gender helps bring out the specific ways whereby transvestites express transgender, and that this may have consequences for how, and to what extent, transvestites make gender trouble and undo gender.

\section{Stigmatized identities in work organizations}

The limited visibility of transvestism in organizations is in all likelihood related to its possible stigmatization. The management of invisible stigmas has attracted increasing interest in recent organizational scholarship in terms of costs and consequences as well as the various practices mobilized to conceal and reveal stigma. Following Goffman (1963), some of this literature has studied how lesbians and gays seek to conceal their sexuality and pass as straight to avoid the stigma associated with a non-straight sexuality whilst others come out to reveal their nonstraight sexuality. Whereas intentional passing practices include fabrication (deliberately lying), concealing (actively withholding information from others) and discretion (avoiding queries), revealing practices include signalling (hinting), normalizing (making the difference seem ordinary and denying that it matters) 
and differentiating (validating the stigmatized identity) (Clair et al. 2005). Rather than a matter of discrete once-and-for-all acts, concealing and revealing is a dynamic and recursive process, where individuals continuously make choices about coming out, or not, in specific situations and to specific people (Croteau et al. 2008). Hence, coming-out is subject to reversal as well as to progress.

According to this literature, concealing stigmatized identities at work may cause isolation, alienation, disengagement and inner turmoil, and impair selfesteem and cognitive capacities as cognitive and emotional resources needed for work are misdirected into laborious efforts to pass (Smart and Wegner 2000; Clair et al. 2005; DeJordy 2008). Fear of disclosure may also negatively affect job attitudes, increase psychological strain and impair work relationships and career outcomes (Ragins 2008). Actual disclosure, however, may not have such effects, but lead to self-verification, relief and enhanced energy as well as reduced stress, role conflict and work/home conflict (e.g. Day and Schoenrade 1997). Furthermore, coming out may enhance interpersonal relations (ibid): by initiating a virtuous circle that encourages others to come out (Creed and Cooper 2008), it may increase visible diversity at work, enhance trust, expand social networks and improve group performance (Clair et al. 2005).

Although this literature acknowledges the recursive nature of concealing and revealing practices as well as their emotional causes and effects, the lived experiences, bodily practices and power relations involved remain underresearched. Moreover, this literature has primarily focused on sexual orientation, some of it even arguing that gender rarely constitutes a source of stigma in modern organizations (see Ragins et al. 2003). As we show further down, transvestism 
goes a long way in problematizing this. But before presenting and analysing our findings, let us present our empirical setting and discuss the methods we employed to generate and analyse our data.

\section{Researching transgender in everyday life and work}

According to Brewis (2005), fellow academics often assume that people who research sexuality do so because of a personal stake in the topic. Even though this paper is about gender, making such an assumption makes sense in our case. This research was spurred by the fact that the first author identifies as a part-time male-to-female transvestite and the second author identifies as the partner of a transvestite. But as argued from rather different perspectives, the personal is not separate from the political, and personal troubles may translate into political problems with implications beyond the sphere of individual experience and interest (cp. Mills 1959 and Hanisch 1970).

Our personal stake in the topic enabled us to immerse ourselves in the field and 'come close to the action' (Watson 2011: 205) whilst utilizing various qualitative methods to generate data about male-to-female transvestites in everyday life and work. The first author has dressed up in public more or less frequently for the past fifteen years, and the second author has often accompanied him on these occasions. However, despite many friends in the LGBT community, we had relatively little contact with other transvestites before starting this research in 2009. For personal reasons and for the possibility of doing research, we therefore joined a transgender support group. At the first meeting we attended the first author was not dressed up but came out verbally as a male-to-female 
transvestite. The second author came out as his partner. At subsequent meetings the first author came dressed up in order to pass as a transvestite, because it felt awkward not being dressed up, and because it felt good to dress up. At the second meeting we both came out as researchers keen to study the gender practices and experiences of male-to-female transvestites in everyday life and work. We did not come out as researchers at the first meeting because it was dominated by a rather fixed agenda, leaving virtually no room for us to speak about our research interest. We also felt that it would have been inappropriate, as newcomers and researchers, to force the discussion in a different direction.

The support group meets once a month in the chambers of a local LGBT organization. Meetings typically last two hours and attract 10-20 participants, primarily straight middle-aged and older part-time male-to-female transvestites but also partners and transsexuals. Many participants are white-collar professionals, some with management careers, but regular participants also include office workers, blue-collar workers, students and retirees. Since the meetings attract a mix of old-timers and newcomers, conversations revolve around a wide range of issues, including shopping and make-up tips, appropriate definitions of transvestism, the prevalence of transvestism and transsexuality, gender identification and sexual orientation, childhood memories, positive and negative encounters with strangers, and positive and negative experiences of coming out to family, friends and colleagues. While some of these topics provoke discussion and disagreement, conversation tends to be cordial.

Participating in fifteen meetings between September 2009 and March 2014 enabled us to observe how other transvestites express gender and to engage in 
numerous conversations about their dressing up practices as well as their various experiences from everyday life and work. We generated unsystematic notes of our observational data from these meetings. We did not take notes during informal conversations as this would interrupt conversation, but we did make unsystematic notes after returning home. While unsystematic notes may lack detail and completeness, they enabled us to record our most significant observations without losing the fresh and intuitive nature of our field experience (Mulhall 2002). With most participatory research, there is a risk that other participants forget that the researcher is more than a participant and thus reveal more than they might otherwise have done. However, in order to recruit interviewees we were careful to remind participants that we were also there in a research role.

So far we have conducted long semi-structured face-to-face interviews with nine part-time male-to-female transvestites. Half of the interviews were conducted by the first author and the other half was conducted by both of us, but we have not sensed that this affected participants' responses. Like most people, transgender people change over time, but all our interviewees identified as transvestites during our data generation period. Our interviews combined a biographical approach (Merrill and West 2009) with a phenomenological approach (Stoller 1997; Engelsrud 2005; Thanem and Knights 2012). During the interviews we asked respondents to talk about their transvestism and their working life experiences. Whereas the biographical approach enabled us to gain insights into the dynamic life-course of respondents rather than mere snapshots of life and work experience, the phenomenological approach enabled us to address embodied feelings and experiences. More specifically, we asked questions about educational background 
and occupational career, about pains, pleasures, problems and opportunities in relation to transvestism within and beyond the workplace, about dressing up, and about passing, gender identification and the expression and concealing of gender identity. Our interviews were conducted between 2010 and 2013 and averaged close to two hours. They were tape-recorded and transcribed verbatim.

Since we were unable to follow participants at work, we complemented these sources with secondary sources to generate further data about transvestites who are out at work and regularly work dressed up. This included journalistic and personal accounts from newspapers, transgender newsletters and personal websites. We found three relevant accounts of transvestites' workplace experience by searching a national newspaper database for the years 2000-2013, by going through the last twenty issues of the support group's newsletter, and by following links at the support group website to publically available personal websites.

Despite increasing tolerance towards sexual and gender diversity in many western cities, transvestism remains a stigmatized issue, at least for some participants in our study. We have therefore anonymized the empirical setting and all data sources. Because of the historical tendency to pathologize transvestism, we had to stress that we were not interested in why people are transvestites but in how, ${ }^{3}$ and some participants needed reassuring that our data would not be used to "out" individual transvestites or to "cure" transvestism. We have sought to validate our findings by making transcripts available to individual interviewees for commentary and by presenting and discussing our findings at a support group meeting. We also discussed our findings informally with individual participants.

We have not exited the field, though, and we continue to participate in the 
support group and to be part of the community. We recognize that this is not wholly unproblematic. Although this is preferable to abrupt disengagement, even gradual exit from a field where one has formed strong bonds with participants may provoke feelings of betrayal and a sense that the community has been exploited by researchers for instrumental purposes (see e.g. Ellis 1995). One may even speculate that our dual roles may restrict other participants' involvement. However, we have not sensed that this is the case. Rather, participants express continued interest in our project, and our continued participation enable us to further validate our findings and give back to the community through our research.

We utilized an iterative method to analyse our data, going back and forth between our empirical material and relevant literature. This enabled us to compare and contrast our findings with key concepts and findings in previous research, highlighting similarities as well as differences and variations. At the initial stages of data analysis, we used thematic template analysis to categorize our material according to overarching themes and subthemes (Cassell 2008). Since we were interested in how transvestites express and experience gender in everyday life and work, it is perhaps not surprising that the expression and repression of transgender emerged as the two main themes, and that their experiences of doing so emerged as a third theme running through these two. These responses necessarily say something about the meanings that our participants attribute to what they do. But more importantly, our continued analysis gave rise to a number of sub-themes that bring out the power relations that conditioned transvestites to repress or express transgender, the practices through which they repressed or expressed transgender, and the experiences and political consequences of doing 
so. Specifically, the power of the gender binary led transvestites to internalize stereotypical gender norms, repress transgender and engage in bodily practices of passing. Whilst conforming to the gender binary, this created much pain and suffering. In contrast, transvestites who paid less attention to the gender binary were able to express transgender by underdoing gender. Whilst challenging the gender binary, this produced largely positive experiences.

It would be naïve to assume that our findings are representative of all transvestites or that our participants were immune to influence from the research process. Nevertheless, we would argue that our findings do important ontological work in fleshing out the embodied expressions and felt experiences of real transvestite lives, and that it enables us to think through the political dimensions of transvestism at work. Our participants shared with us a variety of detailed practices and experiences, and we have no reason to doubt that they were real to them or that they might strike a real chord with others. Let us now present and analyse our findings before we move on to discuss what implications they have for the politics of undoing gender and for organization studies more broadly.

\section{Repressing, expressing and experiencing transgender}

That many transvestites go a long way in order to repress and conceal their transvestism is well documented by Ekins (1997). Our findings confirm this. All our participants argued that they in some way had repressed and concealed their transvestism - from denying it entirely, to merely fantasizing about dressing up, to only dressing up in private, to only displaying it or talking about it in certain settings and with certain people. Attributing feelings of shame or guilt to anything 
transgender, most participants had undergone periods when they had denied their transvestism to themselves or sought to hide it from others. But even though most participants were not open at work about their transvestism, some were open about it and some even dressed up at work, occasionally, regularly or full-time. The duration of their transvestite career and their prior self-denial or self-acceptance seemed unrelated to the degree of display and disclosure and to whether or not they were out at work. Moreover, expressing transgender, in private or in public, was largely associated with positive experiences. We will first discuss how and why they sought to repress their transvestism and how they experienced this.

\section{Repressing transgender}

The power of binary gender norms in work and family life

Concurring with Ekins (1997) and the literature on stigmatized identities (e.g. Clair et al. 2003; Ragins 2008), a number of respondents expected negative reactions from their immediate surroundings and from strangers in the form of stigmatization, discrimination, marginalization and violence should their transvestism become known. In particular, they feared that they would be harassed by colleagues, lose their job and ruin their career prospects if they came out at work or were found out at work. One respondent, who had worked in financial services, described this industry as strict, saying that 'a man in a frock would get fired.' Another respondent, who had recently retired from a long management career in the construction industry, provided the following account:

It was an extreme macho environment, with clients, plumbers, electricians. [...] Coming out would mean being closed off from all social settings. I wouldn't get 
fired, 'cos I was a highly skilled engineer. But I'd be bullied and ostracized by my colleagues.

Similar experiences were reported by others, and one respondent pointed out the particular constraints of working in the arms industry:

I was in the arms industry, and at that time, being a transvestite was equal to being homosexual. People thought transvestites were homosexual, and in the 1960s that was illegal. And particularly in the arms industry you couldn't be homosexual. You'd get fired. You'd be a security threat. Foreign agents could blackmail you.

However, transvestites may struggle more than lesbians and gays to come out, and one respondent who was out as gay at work said he was not yet prepared to come out as a transvestite:

There are 50-60 people working here, and I know more people working for the company [across the country]. If I came out it wouldn't be to a dozen but to a lot more. I don't know what the consequences would be.

Such expectations had led some of our participants to repress their transvestism completely for long periods of time, and it typically took several years before they accepted their transvestism and started dressing up in public. Coming out at work was rarely seen as an option. While none of these participants had personally experienced or observed first-hand the consequences of coming out at work, they had personal experiences of work environments that discouraged them from coming out. Indeed, the power of the gender binary generated an 
overwhelming fear of being harassed and ostracized by colleagues, of being fired and becoming unemployable, and of unknown consequences.

But the power of the gender binary was further related to dominant norms of male careerism and what it meant to be a father and a husband. Some respondents stressed how they had been so immersed in advancing their 'male professional careers' that there was little time to reflect about their transgender identity, let alone to dress up, and one respondent told us how long hours and stress at work constrained his transvestism:

I trained as an engineer by taking evening classes, so there was no time for me to live out a woman. Life was too stressful. [...] When I was promoted to Technical Manager after 25 years I went from working 12 hour days to working overtime only every third week. [...] I developed Type 2 diabetes from the long hours and all stress at work. At 55 I was allowed to step down to working four-day weeks. I still worked 45 hours a week though. It wasn't my boss who demanded the long hours but the projects [I managed].

Others mentioned the constraints of being a husband and a father. Childrearing and other family obligations left little time for dressing up, and transvestites who wanted to keep their transvestism secret from or out of sight of family members experienced that it was difficult to find time alone at home. Yet others mentioned the constraints of married life, and one respondent had recently stopped dressing up because he felt that his non-accepting wife ruined the pleasure for him. Internalizing the gender binary in such ways typically translated into particular practices of doing and performing gender to pass, including 
concealing, discretion and crafting.

\section{Concealing transgender through bodily practices of passing}

Because they expected negative reactions if their transvestism became known, a number of participants engaged in strenuous efforts of concealing and discretion to manage what information they made available to family, friends, colleagues and neighbours. Some of these practices were of a spatial character: participants would use the back door when going out dressed up and seek out shops in areas where they were less likely to bump into people they knew.

Other concealing practices were related to sexual passing, but in a more embodied sense than suggested by previous research on stigmatized sexualities (e.g. Clair et al. 2005). Whereas Garfinkel (1967) and Ekins (1997) emphasize how transgender people engage in passing to avoid revealing that their social gender does not correspond with their biological sex, some of our participants sought to conceal their transvestism by seeking to remove any traces of dressing up. In addition to taking off all feminine garments and paraphernalia, this involved carefully removing nail polish and make-up:

It's not as if I completely hid the feminine before, but I was afraid that someone would find out. So I checked my nails for traces of nail polish. I still don't wear nail polish for work.

For some, concealing their transvestism also involved strenuous efforts to pass as a straight man. Mobilizing a number of social and bodily practices, they sought to craft and harness, though not dishonestly fabricate, an unequivocally macho style, body and identity: 
At work I was a macho man [...]. I wore a mask, and the mask took over the person. My professional self was me but with a mask. [...] With clients I wore a business suit and a slick combed-back haircut. I embodied the standard businessman figure. In the office I dressed more casually, in jeans, T-shirts and clogs. I felt like a slob dressed like that. At building sites I wore jeans and overcoats, respectable work-wear. It had to be obvious that I was an authority figure. I didn't seek to express high status, but it had to be clear that I was higher in status than our construction workers.

For most participants passing seemed more important when in masculine dress. And whereas transvestism and femininity were associated with vulnerability, masculinity was invested with power. At the same time, this posits masculinity as an inevitably unstable masquerade, albeit without the hyperbole highlighted by Butler (1990). Furthermore, it complicates West and Zimmerman's (1987) argument that we always do gender by underscoring that people might wear different masks in different contexts in order to do gender appropriately.

The emotional strain and pain of repressing transgender

Like many of Ekins' (1997) respondents, most of our respondents told us how emotionally straining and painful it had been to repress their transvestism. Some of our respondents argued that they had only recently become aware of their transvestism because they had repressed it so strongly. As the following quote illustrates, others had been highly conscious that they had been repressing something which nevertheless was an important part of them: 'I haven't been a failure as a man, but it's been demanding on me, it's required tension, effort and 
concentration.' One participant, who had taken long-term sick leave from work because he suffered from burnout, related this to having repressed his transvestism for forty years. Another participant talked about his transvestism as having gone through cyclical stages of dressing-up, denial and relapse, comparing his relationship to transvestism with that of an addict struggling to break free from addiction:

The first time I dressed up I was 21. [...] but my reaction was that I was psychologically deviant [...]. So I threw out all my girly stuff. [...] Then I had a relapse after five years [...]. [...] It was an inner drive, [...] an identity need. It wasn't about sex. [...] But I felt remorse again after a few years. It's as if the brain switches into another mode - "I must be ill, I can't go on like this!" So I threw it all out again.

The cyclical nature of repression and release was expressed by other participants too, and it is a fairly common experience amongst transvestites (Ekins 1997). But in addition to highlight the emotional strain of repressing transvestism, it says something about the precariousness of repressive disciplinary regimes: sooner or later, the repressed comes out, in one way or another.

In summary, the power of the gender binary and the consequent association of transvestism with feelings of guilt, shame and fear led participants to internalize dominant norms of masculinity and to repress and conceal their transvestism. Although this generated feelings of strain, pain and depression, participants mobilized a variety of social and bodily practices to craft masculine forms of embodiment and identity. To pass as a straight man, most participants tried to 
remove any traces of dressing up, and some explicitly sought to create a macho appearance whilst working hard to pursue professional distinction through masculine careerism. While repressing transgender involved the appropriate doing of male gender, it negatively undid transgender, making transvestism and any other gender transgression unliveable, or at least less liveable. However, repressive practices were not absolute or in direct opposition to how participants expressed transvestism. Rather than seeking to pass as women and repress any expression of masculinity, they attributed little importance to passing.

\section{Expressing transgender}

\section{Indifference to passing}

All our participants dressed up in public, occasionally or frequently, and most of them came dressed up to the support group and to our interviews. Dressing up involved a range of feminine paraphernalia, including skirts, dresses and heels, bras and tights, wigs and jewellery, make-up and nail polish. Most participants shaved off body hair and some grew their own hair long and had it done in a feminine style.

But whereas passing as a straight man at work had been an important way for some participants to conceal their transvestism from colleagues, few dressed up to pass as women. Some had previously entertained the idea of passing as a woman, but abandoned it when realizing that they were unable to pass. For others it had never been an issue:

To pass as a woman? That's not why I dress up anyway, so it's not important to me. I'd like to look nice, with women's clothes and everything, but that's not 
about passing or pretending to be a woman.

At the same time, some respondents used feminine and androgynous clothes and accessories even when they were not dressed up:

For work I wear my hair long and in a ponytail. A few months ago I found a great hairdresser too. She has dyed my hair and given it a more feminine style. [...] I wouldn't wear a skirt to work, it's not practical. But I often wear nail polish. Not pink nail polish. When I'm not dressed up I'll wear blue nail polish.

Another respondent told us how he let his hair and one of his thumbnails grow: It was fun. The girls at work reacted. Nobody said anything, but one of them made a face when she saw my thumb.' As this suggests, it was not necessarily difficult to do gender inappropriately, though we would be wary of viewing this as an effort to upset the gender binary or as an attempt by his women colleagues to re-impose it.

Indifference towards passing as a woman led most participants to wear casual clothes, plain wigs and little make-up. Nevertheless, the socially dominant look of ordinary women was a major source of inspiration, suggesting that the gender binary was not completely disregarded:

I don't wear too much make-up, and I don't wear party dresses when I dress up in public. After all, most women don't. They wear jeans, very little make-up, usually something unassuming.

Indifference to passing was further expressed through the limited interest in support group initiatives which might have been conducive to help participants pass, including make-up consultations and classes on feminine speech and body 
language.

While dressing up was an obviously embodied practice, participants did not tend to change their body language, bodily gestures or voice. Transvestism was not about being, becoming or pretending to be a woman, and in contrast to Brewis et al. (1997) it was not about taking on a completely different identity:

I don't change my voice or anything [...] I'm the same person. I'm not someone else. [...] I've never been the macho type, but I still enjoy hanging out with my old male friends, watching football, going to the pub.

Indeed, many participants emphasized that transvestism was a matter of expressing one's full identity and personality:

My life blossomed when I accepted my trans identity. I get harmony in here [...] a lot more energy. [...] I'm more tender towards others. I don't keep things inside me any more. I can laugh at myself more. [...] I let the feminine out, the sensitive. [...] I live more fully [...] It's not an escape from life, from the demands of the male role, but about living out a side which is very strong inside.

The significance of passing was further undermined as participants deployed alternative ways to blend into the social background and avoid attention. Whereas Garfinkel (1967) emphasized how transgendered people avoid attention through sexual passing, many of our participants avoided attention by mobilizing ungendered practices of body-work and identity-work. In order to avoid negative reactions but generate positive reactions from strangers, they highlighted the importance of feeling proud about being a transvestite and expressing self- 
confidence through posture, gestures and voice:

Of course you're gonna look suspicious if you try to hide, if you sneak around corners. And you're not gonna meet friendly people if you seem insecure, unconfident and wanna hide. [...] Stand up straight, walk with confidence and be who you are!

This might seem easier said than done, but while some participants had experienced harassment, there was more talk about positive experiences.

\section{Positive experiences of coming out}

Feeling good about oneself as a transvestite, having self-confidence and expressing this when dressed up in public was an important part of the coming out process. Although this may be related to an increasing disregard for the gender binary and its emphasis on passing, participants highlighted the emotional and bodily relief and joy they experienced when "finally" starting to dress up in public:

My transvestism was thoroughly repressed before. [...] It was a liberation when I made the decision to start dressing up.

Participants also spoke of the emotional relief they experienced when acknowledging that there was nothing wrong with them and that there was an entire community of people who were just like them. Coming out to friends and family tended to be less emotional after the fact. As one respondent stated, 'I told my daughters a few years ago. They said "ok". That's all there was to it.' Others told us of partners who encouraged their dressing up, including one participant who said that a former girlfriend broke up with him because he did not dress up 
frequently enough.

But as our discussion of repressive practices suggests, it seemed more difficult to come out at work. Meanwhile, transvestites who have come out at work and dressed up at work regularly or full-time seem to have had largely positive experiences. For instance, one participant who travelled dressed up on a business trip abroad felt that s/he was met by some initial puzzlement from the overseas hosts but still felt completely welcomed. Another participant, who worked as a professional in a manufacturing firm, described his experience of coming out at work as follows:

I was really nervous but I felt it was time to take the step. Neither my family nor my friends had a problem with my transvestism [...] At the same time my colleagues found out. In just a few hours I got fifteen hugs from my women workmates. I was completely gobsmacked!

This participant further emphasized the positive experiences and incremental nature of his coming-out process, from never dressing up at work to dressing up occasionally and then full-time.

I told a workmate that I'd been to a make-up course. I showed her photos of myself as a woman. That was the first step. Then I said I'd like earrings for my birthday. I told a few more girls at work. And for my birthday my workmates gave me a pair of earrings. My boss handed them over - it was nothing weird about it. Soon the news spread that I was a transvestite. [....] Then two colleagues, a man and a woman, asked me why I didn't always come to work as Camilla. They encouraged me, and since then I've always come to work in 
women's clothes. [....] [Later] The company changed my name in the personnel files so the payroll said Camilla instead of Carl, and every morning when I scanned my entry card the display said "Welcome Camilla". When the company invited all the women managers to a gathering at head office I was invited. That gesture meant a great deal.

Meanwhile, some participants experienced their transvestism as an advantage at work. Some felt that they had become more efficient at work. As one respondent argued, 'I put more energy into work now. I don't have to hide or worry about being found out anymore.' Another participant had been told by one of his managers that he was fully respected by everybody at work because people felt that he was open about who he was and stood up for who he was. For two participants, their transvestism had apparently been a direct advantage when seeking new jobs. One of them, who works in a staff training function, said he was recruited for this job because management knew he was a transvestite, and he actively utilized his transvestism to be more effective in his work role:

They wanted me. [...] As a transvestite who is out in public I have noticed that I gain more respect and that people listen when I am open about my personality.

He had even started utilizing his transvestism during training sessions in order to challenge prejudices related to the gender binary and beyond. Further, he argued that as he had opened up to his colleagues, other employees had started opening up to him, and that the organizational atmosphere had become more open: 'My boss and several of my co-workers have told me that the fact that I'm out at work has increased their tolerance and acceptance of all minorities.' 


\section{Negotiating the gender binary}

Although passing was not an issue for most of our participants, conforming to dominant gender norms did seem rather important for certain people in their surroundings. This point may be illustrated by the following quote from a participant who was explicitly welcomed out of the closet and encouraged to dress up at work:

When I came out to my closest boss, she said "Great! We're gonna have to get you a skirt then!"

Later, he told us that the "girls at work" had decided to organize a "reversed roles" dress-up party. Notwithstanding the positivity of these incidents, they do strike a chord with previous findings about straight colleagues casting transsexuals in binary schemes of gender-appropriate dress (Schilt and Connell 2007).

But we would also argue that participants challenged the gender binary. While this last respondent had started to wear certain feminine accessories at work, he said he found it impractical to be fully dressed up at work and continued instead to craft a more androgynous look. In a more explicit way, another participant, who had taken a feminine first name, had strongly refused masculine and feminine norms of gender appropriate dress on an occasion when her nearest boss had addressed her with her former male name, and suggested that s/he 'shouldn't wear skirts this short':

He said this in the common room in front of everybody, so then I enlightened him about the Anti-Discrimination Act. 
This participant further argued that it was much easier to work with women colleagues after coming out as a transvestite but more difficult to work with men:

The first time I came dressed up to work, people called between different departments at the factory to share the news that I was wearing women's clothes. [...] Two male colleagues spotted me as I was walking across the yard, and took a detour to avoid meeting me. But as they were entering the other building, they turned their heads and stared! [....] Men don't generally know how to work with me as a transvestite. One of my male colleagues who had been very friendly before [I came out] stopped talking to me. But I've realized that's his problem.

The participant who worked in staff training reported similar problems, and highlighted how being out as a transvestite had become a question of power.

some of my old colleagues had a problem with me coming out. That a man dresses in women's clothes provokes reactions. Many [reactions] and strong [reactions]. When I wear women's clothes I signal that I step down in status, that I give up my male status. That provokes. [...] It's about power. [...] Not just men's power, but women's power positions too are questioned. If I express myself as a woman I encroach on their femininity, I become a threat.

Consequently, he did not always dress up at work, and he had stopped doing so during training sessions, as that tended to distract participants from the topic at hand.

Still, participants who were out at work reported more positive than negative 
experiences. Moreover, their indifference to passing enabled them to express transgender somewhat independently from the gender binary, and in spite of attempts by colleagues to correct or constrain their transvestism according to the gender binary.

\section{Discussion}

\section{The politics of undoing gender by underdoing gender}

On the whole, our findings elaborate the conditions, identity practices and effects of repressing and expressing transgender in everyday life and work. Whereas our findings about repression highlight the costs and consequences for individuals of concealing their transvestism, our findings about expression raise questions about the power and identity politics of underdoing gender within and around organizations. This has implications for the undoing of gender and for dominant identity forms more broadly. But in order to discuss this, we first need to say a bit more about the identity practices of transvestites who were out at work, the meanings they attributed to these practices, and how and why they brought them into the workplace.

As participants dressed up to express transgender rather than disguise incoherence between biological sex and social gender, we would argue that they were underdoing rather than doing gender. Indifferent to passing, and identifying with feminine and masculine forms of expression, they mobilized a variety of social and bodily identity practices whereby they added, removed and combined masculine, feminine and un-gendered practices and attributes. They talked about their transvestism with colleagues, they wore feminine garments and 
paraphernalia, and they tended to retain their masculine or androgynous voice. Whereas certain garments and paraphernalia were used in order to express femininity or androgyneity, changing one's voice was seen to abandon too much of one's personal identity. Meanwhile, participants argued that being out required self-confidence and self-assertiveness, and they sought to express this through body language and vocal patterns. Although body language, voice and gestures are often seen as gendered, we did not sense that participants regarded the selfconfidence mobilized to assert a transvestite identity as particularly masculine or feminine.

Participants who brought their transvestism into work did so incrementally, subtly, or discontinuously: incrementally, by first telling friends at work, then dressing up occasionally, and finally dressing up full-time; subtly, by only wearing a few feminine garments and paraphernalia; and discontinuously, by moving back and forth between wearing women's clothes and men's clothes at work, dressing up regularly but not full-time. Either way, dressing up at work was about personal wellbeing and identity expression: since their transvestism could not be separated from who they were, it was painful to be completely different at work and home.

Nevertheless, we would argue that their underdoing of gender went some way in making gender trouble, challenging the gender binary and undoing gender. But unlike previous arguments, transvestites in our study did not make gender trouble simply by being transgender (see Brewis et al. 1997) or by pursuing an activist agenda of gender transgression (see Connell 2010). Rather, gender trouble played out in more nuanced ways. Indeed, some of their colleagues were troubled by their transvestism, and they were troubled enough to terminate previously 
cordial working relationships. Other colleagues did not seem troubled by their transvestism as such, but their attempts to correct and constrain dress practices suggests that they did also not seem fully comfortable with transvestites' underdoing of gender.

Although our study did not provide direct insights into the sentiments and intentions of transvestites' colleagues, this suggests that some colleagues tried to re-impose the gender binary. One could therefore argue that more open-ended gender expressions and gender relations were undermined and negatively undone by being made less liveable. But more importantly, we would argue that reimposing binary gender norms in these ways revealed the weakness of the gender binary: had the gender binary been sovereign, there would have been no need to re-impose it. Furthermore, some of our participants were able to challenge the gender binary even without intending to do so. Despite constraints that made transvestism less liveable, they were able to positively undo the gender binary insofar as they were able to express their transvestism and make it liveable, even when this required a particular assertiveness. And in the case of the respondent working in staff training, transvestite underdoing of gender seemed to further undo gender relations at work by opening up the organizational atmosphere and making colleagues reflect about their own prejudices and gender identities.

Of course, this is a rather different notion of gender trouble and undoing gender than the narrow understanding adopted by West and Zimmerman (2009) and Connell (2010), who reduce gender trouble to intentional efforts to dismantle the gender binary. By suggesting that gender trouble is not necessarily intentional, and that people may undo gender by challenging rather than dismantling the 
gender binary, we posit a view that is arguably more in line with Butler's original (1990, 1993, 2004). Butler (1993) acknowledged that gender trouble is not necessarily successful in radically changing gender relations. But unless people start embodying gender differently, the gender binary will never be challenged. Furthermore, we would argue that gender trouble is even evident insofar as cis people re-impose the gender binary when encountering transgender people. Consequently, the relationship between positive and negative undoing is unlikely to be dualistic. It is rather a question of making different gender expressions more or less un/liveable.

These findings further contest extant understandings of doing and undoing gender within and beyond organization studies, which continue to maintain a causal sex-gender relationship where social gender corresponds to biological sex. In particular, West and Zimmerman's (1987) emphasis on doing gender appropriately through passing ends up privileging gender expressions that obscure the constructed nature of gender and the constructed nature of the causal sex-gender relationship. As passing gives the impression that sex corresponds to gender even when it does not, it works to maintain social order and the underlying gender binary. In a different vein, previous research in organization studies, which argues that women may positively undo gender by not embodying female stereotypes at work (e.g. Kelan 2010), maintains the causal sex-gender relationship by focusing on women who are still within the realm of doing female gender.

In contrast, transvestites who underdo gender move between genders, embody a terrain in-between and beyond genders, and clearly express transgender 
forms of embodiment and identity. Doing so, they reveal the constructed nature of the causal sex-gender relationship as well as the constructed nature of gender, and they subvert the causal sex-gender relationship by openly showing that there is no necessary correspondence between the two. Admittedly, such questioning may even be accomplished by gender queering and hyperbolic drag. But unlike gender queering, transvestite underdoing of gender rarely takes an activist form and it is rarely full-time. And unlike drag, it pays much less attention to male-centred stereotypes of female appearance.

\section{Power, resistance and identity in organizations}

Given previous discussions in organization studies about transgender as transgressive (Brewis et al 1997; Schilt and Connell 2007) and given the expected stigmatization of transgendered people and the limited visibility of transvestites in organizational life, transvestism actualizes broader issues of power, resistance and identity in organizations. Hence, it is appropriate to ask what the expected stigmatization and limited visibility of transvestism says about the subjugation of identity in organizations, and what transvestite expressions of transgender say about their ability to make gender trouble and resist dominant forms of identity at work.

As mentioned above, we found that transvestites who had come out at work had largely positive experiences, thus confirming speculation in previous research about a virtuous circle of coming out at work (see e.g. Clair et al. 2005). While this may be reflective of increased tolerance towards gender and sexual diversity in western societies and work organizations, it also problematizes recent studies on 
subjugation and identity expression under neo-normative control (e.g. Fleming and Sturdy 2009). Though not encouraged to "just be themselves", participants in our study who were out at work were largely accepted by their colleagues for who they were and turned out to be. However, in contrast to these studies, and even though transvestism seemed to be a work-related advantage for one participant, none of them worked in corporate cultures that promoted self-expression or diversity. Hence, their coming out was not enabled by organizational processes of subjugation that explicitly promoted a wider range of identity expressions at work. Rather, by dressing up at work, they departed from dominant norms of employee subjectivity.

Further, the fact that so few transvestites are out at work suggests that transvestism remains a sensitive issue in work organizations, that expected stigmatization remains prevalent among transvestites who are not out at work, and that people in work organizations continue to be subjugated by and suffer from binary gender norms. Even though mainstream claims for diversity and selfexpression at work indicates that the days of Organization Man are long gone, transgender and transvestism rarely figure in such claims. On the contrary, corporate websites, recruitment campaigns and media coverage of business leaders typically depict people who do gender appropriately. While this may discourage transvestites from coming out, transvestites who are out at work may still challenge predominant notions of the ideal employee and the ideal manager, particularly insofar as they underdo gender.

We acknowledge that this may generate risks, costs and consequences. Maleto-female transvestites who underdo gender risk losing both the privileges that 
come with being a man in male-dominated organizations and the unproblematic organizational status enjoyed by women and men who do gender appropriately. But it may also generate opportunities, and thereby problematize that dressing up is necessarily a misnomer (see e.g. Brewis et al. 1997). That some men willingly and obviously give up gendered privileges and explicitly assert their right to do gender "inappropriately" challenges the taken-for-granted nature of such privileges, and suggests that organizations and their power relations could be challenged and positively undone.

\section{Conclusion}

In this paper, we have argued that transvestites maintain the gender binary and negatively undo gender insofar as they repress and conceal their transvestism, but that transvestites may positively undo gender in everyday life and work by underdoing gender. Whereas the repression of transvestism is conditioned by the coercive, constraining and discriminatory nature of the gender binary, transvestites who underdo gender may challenge though not likely dismantle the gender binary, gender hierarchy and prevailing notions of the ideal employee. This dynamic of the negative and positive undoing of gender has broader implications for organization studies.

Firstly, the transvestites in our study may provide an extreme case that mirrors how most people struggle to manage and discipline their identities. Struggle is a particularly appropriate word here, as the study suggests that repression is rarely tenable in the long run. As repression gives rise to relapse and expression rather than control, it imbues the internalized regimes whereby we try 
to manage our identities with a fundamental vulnerability.

Secondly, and at a time when appeals are made to shift attention from "small" issues of identity, oppression and recognition to "big" issues of class, exploitation and re-distribution (e.g. O'Doherty et al. 2012), our study reasserts the importance of the former whilst indicating a pressing need to re-connect with the latter. We acknowledge that organizational elites and market regimes subject people to oppression and exploitation. Our point is that oppression and exploitation is reproduced as people internalize dominant organizational subjectivities. That transvestites repress their transvestism in everyday life and work out of fear that it would ruin their careers provides further reason to interrogate the mutual production of oppression and exploitation, and to explore positive trajectories of recognition, re-distribution and expression. But real change is not possible without alternatives to the status quo. As transvestites stop repressing and start expressing their transvestism, they provide a strong example of how oppressive conditions may be challenged and how people may embody and dwell along alternative trajectories of life and work.

\section{Notes}

1. Whereas West and Zimmerman (1987) conflate transgender with transsexuality, Ward and Winstanley (2003) confuse transsexuality with sexual orientation.

2. As West and Zimmerman (1987: 131) explicitly assume that transvestites must pass, they further conflate transvestism and transsexuality.

3. Certain kinds of transvestism remain listed as a sexual and gender identity 
disorder in the fifth edition of the American Psychiatric Association's (2013) Diagnostic and Statistical Manual of Mental Disorders.

\section{References}

American Psychiatry Association (2013) DSM-5: Diagnostic and Statistical Manual of Mental Disorders. Arlington VA: American Psychiatry Association. Brewis, J. (2005) 'Signing my life way? Researching sex and organization', Organization 12(4): 493-510.

Brewis, J., Hampton, M.P. and Linstead, S. (1997) 'Unpacking Priscilla: Subjectivity and identity in the organization of gendered appearance', Human Relations 50(10): 1275-1304.

Bruni, A., Gherardi, S. and Poggio, B. (2004) 'Doing gender, doing entrepreneurship: An ethnographic account of intertwined practices', Gender, Work \& Organization 11(4): 406-29.

Butler, J. (1990) Gender Trouble. New York: Routledge.

Butler, J. (1993) Bodies That Matter. New York: Routledge.

Butler, J. (2004) Undoing Gender. New York: Routledge.

Cassell, C. (2008) 'Template analysis', in R. Thorpe and R. Holt (eds) The Sage Dictionary of Qualitative Management Research, pp. 220-222. London: Sage.

Clair, J.A., Beatty, J.E. and Maclean, T.L. (2005) 'Out of sight but not out of mind: Managing invisible social identities in the workplace', Academy of Management Review 30(1): 78-95.

Connell, C. (2010) 'Doing, undoing, or redoing gender? Learning from the workplace experiences of transpeople', Gender \& Society 24(1): 31-55. 
Creed, D. and Cooper, E. (2008) 'Introduction: Offering new insights in GLBT workplace experiences', Group \& Organization Management 3(5): 491-503.

Creed, W.E.D. and Scully, M.A. (2000) 'Songs of ourselves: Employees' deployment of social identity in workplace encounters', Journal of Management Inquiry 9(4): 391-412.

Croteau, J.M., Anderson, M.Z. and VanderWal, B.L. (2008) 'Models of workplace sexual identity disclosure and management: Reviewing and extending concepts', Group \& Organization Management 33(5): 532-65.

Czarniawska, B. (2007) 'Doing gender unto the other: Fiction as a mode of studying gender discrimination in organizations', Gender, Work \& Organization 13(3): 234-53.

Day, N.E. and Schoenrade, P. (1997) 'Staying in the closet versus coming out: Relationships between communication about sexual orientation and work attitudes', Personnel Psychology 50(1): 147-63.

DeJordy, R. (2008) 'Just passing through: Stigma, passing and identity decoupling in the workplace', Group \& Organization Management 33(5): 504-31.

Ekins, R. (1997) Male Femaling. London: Routledge.

Ekins, R. and King, D. (2006) The Transgender Phenomenon. London: Sage.

Ellis, C. (1995) 'Emotional and ethical quagmires in returning to the field', Journal of Contemporary Ethnography 24(2): 68-98.

Engelsrud, G. (2005) 'The lived body as experience and perspective: Methodological challenges', Qualitative Research 5(3): 267-84.

Fleming, P. and Sturdy, A. (2009) “Just be yourself!”: Towards neo-normative control in organisations?', Employee Relations 31(6): 569-83. 
Garfinkel, H. (1967) Studies in Ethnomethodology. Englewood Cliffs NJ: Prentice-Hall.

Goffman, E. (1963) Stigma. Englewood Cliffs NJ: Prentice-Hall.

Green, E. and Peterson, E.N. (2006) LGBTTSQT Terminology. Riverside CA: TransAcademics, LGBT Resource Center. (www.trans-academics.org)

Greer, G. (1999) The Whole Woman. London: Doubleday.

Hanisch, C. (1970) 'The personal is political', in S. Firestone and A. Koedt (eds) Notes From the Second Year: Women's Liberation. New York (pamphlet).

Kelan, E. (2010) 'Gender logic and (un)doing gender at work', Gender, Work \& Organization 17(2): 174-94.

Linstead, S. and Pullen, A. (2006) 'Gender as multiplicity: Desire, displacement, difference and dispersion', Human Relations 59(9): 1287-1310.

Merrill, B. and West, L. (2009) Using Biographical Methods in Social Research. London: Sage.

Mills, C.W. (1959) The Sociological Imagination. Oxford. Oxford University Press.

Mulhall, A. (2002) 'In the field: Notes on observation in qualitative research', Journal of Advanced Nursing 41(3): 306-13.

Namaste, K. (1996) 'Queer theory's erasure of transgender', in B. Beemyn and M. Elianon (eds) Queer Studies: A Lesbian, Gay, Bisexual, \& Transgender Anthology, pp. 183-203. New York: NYU Press.

O’Doherty, D., Bresnen, M., Grugulis, I., Hassard, J., Hodgson, D. and Hyde, P. (2012) 'Extending the limits of neo-liberal capitalism', Call for sub-theme proposals, The 8th International Conference in Critical Management Studies, University of Manchester. 
Powell, A., Bagilhole, B. and Dainty, A. (2009) 'How women engineers do and undo gender: Consequences for gender equality', Gender, Work \& Organization 16(4): 411-28.

Pullen, A. and Knights, D. (2007) 'Editorial: Organizing and disorganizing performance', Gender, Work \& Organization 14(6): 506-11.

Ragins, B.R. (2008) 'Disclosure disconnects: Antecedents and consequences of disclosing invisible stigmas across life domains', Academy of Management Review 33(1): 194-215.

Ragins, B.R., Cornwell, J.M. and Miller, J.S. (2003) 'Heterosexism in the workplace: Do race and gender matter?', Group \& Organization Management 28(1): 45-74.

Raymond, J. (1979) The Transsexual Empire. Boston: Beacon.

Schilt, K. and Connell, C. (2007) 'Do workplace gender transitions make gender trouble?', Gender, Work \& Organization 14(6): 596-618.

Smart, L. and Wegner, D.M. (2000) 'The hidden costs of stigma', in T. Heatherton, R. Kleck, M. Hebl and J. Hull (eds) The Social Psychology of Stigma, pp. 220-42. New York: Guilford Press.

Stoller, P. (1997) Sensuous Scholarship. Philadelphia: University of Pennsylvania Press.

Thanem, T. (2004) 'The body without organs: Nonorganizational desire in organizational life', Culture and Organization 10(3): 203-17.

Thanem, T. (2010) 'Free at last? Assembling, producing and organizing sexual spaces in Swedish sex education', Gender, Work \& Organization 17(1): 91-112.

Thanem, T. (2011) 'Embodying transgender in studies of gender, work and organization', in E. Jeanes, D. Knights and P. Yancey Martin (eds) Gender, Work 
and Organization Handbook, pp. 191-204. Oxford: Wiley.

Thanem, T. and Knights, D. (2012) 'Feeling and speaking through our gendered bodies: Embodied self-reflection and research practice in organisation studies', International Journal of Work Organisation and Emotion 5(1): 91108.

Tyler, M. (2012) “'Glamour girls, macho men and everything in between”: Un/doing gender and dirty work in Soho's sex shops', in R. Simpson, N. Slutskaya, P. Lewis and H. Höpfl (eds) Dirty Work, pp. 65-90. Basingstoke: Palgrave Macmillan.

Tyler, M. and Abbott, P. (1998) 'Chocs away: Weight watching in the contemporary airline industry', Sociology 32(3): 433-50.

Ward, J. and Winstanley, D. (2003) 'The absent presence: Negative space within discourse and the construction of minority sexual identity in the workplace', Human Relations 56(10): 1255-80.

Watson, T. (2011) 'Ethnography, reality, and truth: The vital need for studies of 'how things work' in organizations and management', Journal of Management Studies 48(1): 202-17.

West, C. and Zimmerman, D.H. (1987) 'Doing gender', Gender \& Society 1(2): 125-51.

West, C. and Zimmerman, D.H. (2009) 'Accounting for doing gender', Gender \& Society 23(1): 112-22. 